【総 説】

対寒反応をとおしてみた鍛練とその効果

熊本大学名誉教授

緒 方 維 弘*

\title{
A CONSIDERATION ON EFFECT OF TRAINING THROUGH THE RESPONSES OF COLD EXPOSURE
}

\section{Korehiro Ogata}

\section{I 鍛練への考察の出発点}

本篇は筆者がその主研究課題としている体温調 節機能のうち, 寒冷への反復曝露をおのずからな る対寒鍛練とみなし，てれを通じてよびおてされ る反応の消長を通じて, 身体鍛練とその効果につ いての筆者なりの考え方をまとめてみたものであ る。

すべて生体では刺激に対沁して反応するととが その 調節機構としての基礎的な特性をなしてい る。しかし単に生物の剌激に対する反応という限 りでは, それが形態的であるか，あるいは生理学 的なあのであるかにかかわらず，刺激に対する直 接的な応答を意味するにとどまる。ところが刺激 がすでに習慣していた範囲を越し，かつその刺激 が長くつづいて，既得している反応だけでは，そ れに対処することができなくなった場合は，その 生物の官能の平衡は破れざるをえない。とのよう な事態に対しては生体はその平衡を再建し維持し ようとする能力を賦与されている。てれを生体の 適応能というが, かかる能力を駆使して, 対象之 なっている生物官能をより高い次元において活動 させるように積極的な促進を意四するとてろに鍛 練の意義を有する。したがって鉎練の実施に際し てまず留意しなければならないのは，目標とする 生体官能が，負荷しようとする鉎練に対して適応 する性能を俱有しているものであるか否かの点で ある。両者があしも無縁のものであるならば，た とえ鍛練が負荷されたとしてあ，ただ困䣏之疲弊 のみが残されることになる。ひいては鈠練効果の
完璧を期するためには，まずそれの適伈成立機序 に対する正確な判断を持っていなければならな い。例えば 1951 年にニューヨークで行なわれた 「寒冷障害に関するシンポジュウム」の席上，こ の領域の権威者である Western Ontalio 大学の Burton 教授 ${ }^{11}$ は, 動物の組織の熱遮断度が冬季に 大きくなる現象をさして，それは寒さに対する適 応となすよりあ，むしろ暑さに対する適応現象の 一面であると解すべきであると発言しているが, そのいずれの解釈をとるかによって対寒適応に占 むる組織の熱遮断という大きな反吣への対処の方 向がおのずから制約をてうむらざるをえない。さ らに同会合の席上, 寒暑を対象とする生理学研究 に生涯をささげられている Rochester 大学の Adolph 教授1は「寒さに向っての適応現象は動物 においてはたしかに存在しているが，ヒトにおい ては認めがたい」とされている旨が記載されてい る。そのよって来るところは, 対寒適応の本体を なすすのは, 体熱産生能力の増進でなければなら ないが, 動物では歴然たる産熱増進があるのに反 して，ヒトでは温度感覚的に中正な環境条件下で は基礎産熱量の増大はむたらされないというので ある。すなわち非ふるえ性産熱の増進がヒトにも 存するか否かが問題になっている。現在のとてろ この意味での適応はヒトにす存するとなす研究者 あ多くなっているが, Adolph 教授の如き大先達 の言が, この領域の研究の方向づけと進歩に大き く貢献したことはたしかである。

対寒反応に適応現象が存在することを単的に示 す 1 つの好例として，凍瘡（しむやけ）に関する

\footnotetext{
* 現熊本女子短大栄䓹生理学教室 教授 Dept. of Nutrition
} 
久野教授一門の報告4)がある。そもそも凍瘡は組 織の凍結を前提条件とせず，比較的軽い寒冷によ って真皮の血管が拡張して，その壁を透して血液 の水分が多量に組織間へ瀘出するととによってお こる障害である。したがって酷寒地よりあかえっ て湿暖な日本などでよく見受けられる。しかもそ の発症は厳寒季よりあむしろ晚秋から冬にかけて のころか，あるいは冬を越した早春に多い。いず れにあせよ本症は本来寒さに出会うことによって からこそおこる障害であるのに，上述のような発 症期を呈することは見方によっては奇異の感を受 ける。久野教授はての発症期についてつぎのよう な見解を述べている。すなわち「しもやけが寒威 未だ烈しからざる初冬に瀕発し，しかすその大半 が厳冬の頃に入れば自然に治癒するととは，てれ は寒気の鍛練がしあやけに対する抵抗力を増すた めであろうという推定を喚起させる事実である」。 このととは瑓瘡の発症機序に立脚して, 外来侵襲 と耐性增進との相対的優劣があたらした結果を明 示しているものである。早春凍瘡も春温による耐 性の消退時に襲われた春寒によるすのと考えた い。

しかしてのように対寒鉎練による効果の存在は たしかであるとしてす, 鍛練そのあのは元来生体 にとっては未習熟の侵襲をくりかえされるととに ちがいないのであるから，とれは在来の生体官能 平衡からすれば，まず異化的作用をよびおてすす のであることをまぬかれない。そてには当然銭練 の至適負荷量という問題がおてってくるし，ての 問題こそが生活の実際にとっては最も身近なすの として考えなければならなくなる。

\section{II 耐寒性の出身地別的差異に関する一実験}

対寒鍛練の至適負荷量に関する検討のたたき台 的な実験例として，筆者ら (7) が 1940 年に経験し た北満佳木斯で同地の医大生についての耐寒性の 出身地別的差異に関する成績をかかげる。出身地 別的観察をまずとりあげたのは，生来くりかえさ れた環境気象の影響がそれぞれの土地の住民にお のずからなる対寒鈠練の相巽をあたらしたであろ うことが想像されるからである。

この実験の主体を佳木斯医大生に求めたのは, 被検者がこの 実験に 臨むまでに 経歴した 生活様
式, 換言すれば寒冷に対する馴れの程度の差をう かがおうとすることが実験目的の第1であるから. 実験時の生活条件は可及的に等しい者を集めなり ればならないが，ての点ての被検者たちはすこぶ る好条件をそなえていたととに因る．すなわち彼 らは第 1 に18〜19才の日本内地人に限られている のであり，第 2 には全員とあその年の 4 月にはじ めて渡満し, 最初の満洲の冬を経験しつつあった こ之, 第 3 に全員同大学寄宿舎に居住しており, その起居はすへて軍隊式に一律に行なわれていた こと，さらに第 4 には食事，衣服は全部官給であ ったからである。かくして北海道および東北地方 出身者を北方出身者とし, 関西以西九州出身者を 南方出身者と認め, 実験は毎回両群から 1 名ずつ を選び，同時同一条件のあとに，乙んな組合せ 10 組につき，1組については 2 回ずつ対寒反応比較

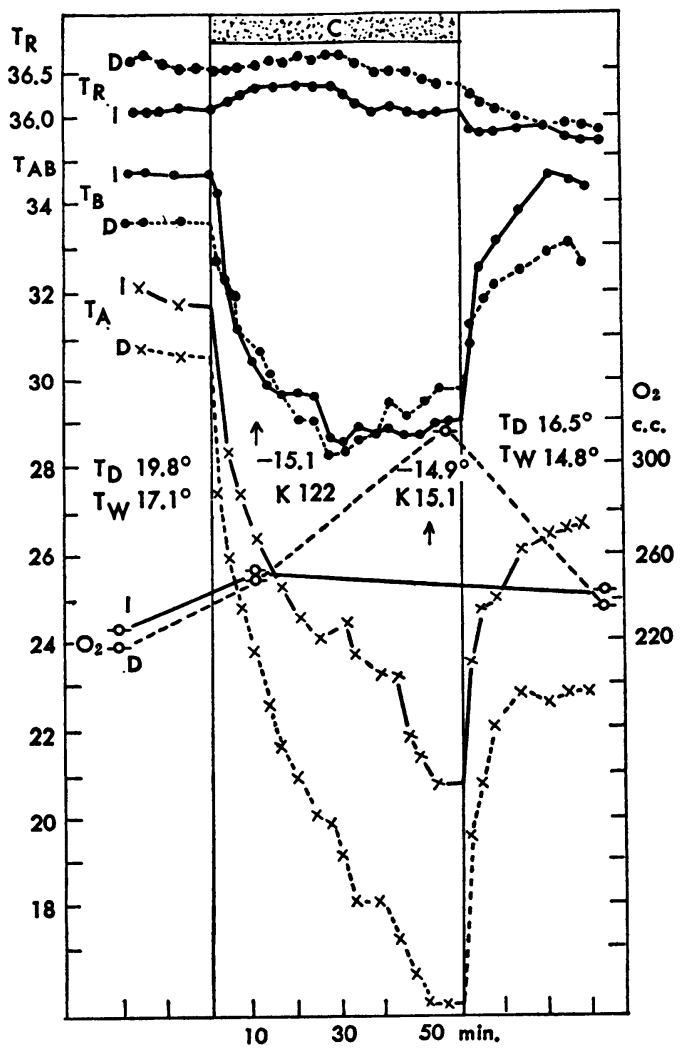

$T_{R}$ 直 腸 温

TB 胸部皮虚温

$\mathrm{Tw}$ 湿球気温

C 寒冷曝露

TA 前膊皮席温

$\mathrm{O}_{2}$ 毎分酸秲消費量

TD 乾球気温

$\mathrm{K}$ 凍 力

D 被検者(北)

I 被検者(南)

困 1 寒冷曝露比較試験 
附表

\begin{tabular}{|c|c|c|c|c|c|c|c|c|c|c|c|}
\hline \multirow{2}{*}{\multicolumn{2}{|c|}{$\begin{array}{l}\text { 被 験 } \\
\text { 出 身 }\end{array}$}} & \multirow{2}{*}{$\begin{array}{l}\text { 者 } \\
\text { 地 }\end{array}$} & \multirow{2}{*}{${ }_{\mathrm{cm}}{ }^{\text {長 }}$} & \multirow{2}{*}{${ }_{\mathrm{kg}}^{\text {重 }}$} & \multirow{2}{*}{$\begin{array}{c}\text { 皮下脂肪 } \\
\mathrm{mm}\end{array}$} & \multicolumn{4}{|c|}{ 酸素消費量cc（毎分平方m） } & \multirow{2}{*}{$\begin{array}{ll}\text { 代 } & \text { 謝 } \\
\text { 型 } & \text { 式 }\end{array}$} & \multirow{2}{*}{$\begin{array}{l}\text { 皮 温 } \\
\text { 型 式 }\end{array}$} \\
\hline & & & & & & 出 & 寒 & 冷 & 入 & & \\
\hline I & & 南 & 174.0 & 54.5 & 8 & 135 & 151 & - & 144 & I & 別 \\
\hline ID & & 北 & 172.5 & 59.0 & 8 & 127 & 145 & 185 & 138 & I & 中 \\
\hline$(\mathrm{H}$ & & 南 & 168.2 & 63.5 & 10 & 141 & 149 & 153 & 121 & II & 同 \\
\hline A & & 北 & 161.0 & 58.5 & 15 & 135 & 157 & - & 152 & I & 同 \\
\hline E & & 南 & 167.5 & 64.0 & 16 & 129 & 148 & 158 & 130 & II & 同 \\
\hline B & & 北 & 168.0 & 67.0 & 12 & 127 & 159 & 139 & 132 & I & 同 \\
\hline F & & 南 & 166.1 & 65.0 & 16 & 128 & 156 & 146 & 141 & I & 中 \\
\hline$\lambda_{C}$ & & 北 & 169.4 & 57.0 & 12 & 125 & 150 & 150 & 120 & II & 別 \\
\hline G & & 南 & 171.7 & 76.5 & 15 & 130 & 162 & 147 & 154 & III & 中 \\
\hline$I_{D}$ & & 北 & 172.5 & 59.0 & 8 & 128 & 135 & - & 137 & III & 同 \\
\hline ( I & & 南 & 174.0 & 54.5 & 8 & 121 & 125 & 138 & 137 & I & 別 \\
\hline A & & 北 & 161.0 & 58.5 & 15 & 130 & 147 & 161 & 136 & I & 同 \\
\hline F & & 南 & 166.1 & 65.0 & 16 & 135 & 151 & 191 & 142 & I & 同 \\
\hline B & & 北 & 168.0 & 67.0 & 12 & 141 & 147 & 150 & 130 & II & 同 \\
\hline${ }^{E}$ & & 南 & 167.5 & 64.0 & 16 & 130 & 142 & 161 & 134 & I & 同 \\
\hline Ic & & 北 & 169.4 & 57.0 & 12 & 132 & 136 & 172 & 127 & II & 別 \\
\hline A & & 北 & 161.0 & 58.5 & 15 & 129 & - & 147 & 123 & II & 中 \\
\hline C & & 北 & 169.4 & 57.0 & 12 & 131 & - & 154 & 131 & II & 別 \\
\hline (H & & 南 & 168. 2 & 63.5 & 10 & 129 & 137 & 142 & 122 & III & 同 \\
\hline$I_{G}$ & & 南 & 171.7 & 76.5 & 15 & 136 & 161 & 153 & 146 & III & 中 \\
\hline
\end{tabular}

試験を行なった。被検者の服装は毛シャツ 2 枚に 統制し，下半身および手，耳介などは十分に防寒 させた。実験当日の朝食はこれを廃し，15 20 $\mathrm{C}$ の室中に 1 時間以上，つづいて $-15^{\circ} \mathrm{C}$ ，ほ之 んど無風の屋外に50分間さらし，再入室後さらに 約 1 時間，すべて仰臥位をとらせて，直腸温，胸 部皮淍温および前腕皮唐温を連続測定した。また 各人につき寒冷曝露前 1 回, 曝露中 2 回, 温暖室 復帰後 1 回の計 4 回酸素消費量（産熱量）を測定 した。

図 1 はその 1 例で実験状況を示すあのであり， また附表はその全成績を集めて表示したものであ る。

皮暍温は寒冷曝露とともに著落する。その落ち 方は四肢の温度が稫幹部のそれに比し著しく急激 かつ低温にまで下降する型のもの之，両者の差が 比較的少なく，とあに程度の差てそあれ同一経過 をたどって下降する傾向の強いすの，さらに両者 の中間を行くあのとがあるのであって，前者を別 行型, 次者を同行型, 後者を中間型とし, 附表に はその状況を別，同，中の略号を以って記入し
た。このような分け方をしてみたのは，重要臟器 を蔵する軀幹部の温度は可及的に不変にたすち， 四肢の温度は下降させるととによって身体加らの 放熱量の減少をはかるものの方が耐寒上有利では ないかとの考えによるものである。結果は皮庿温 下降の絶対量でも，またこのような皮庯温下降の 型でも, 各個人では毎回同じ経過をとる傾向が強 いが，出身地および体格との相関は認めがたかっ た。ただ皮膚温の高低と皮下脂肪の厚さとの間に は, 皮下脂肪の厚い者は薄い者に比して6.5対2.5 の割合で低いという関係が見られた。

直腸温については寒冷曝露前における值に対す る曝露後の比較高において, 皮下脂肪の厚い者は 薄い者に比して 7 対 2 の割合で高くあらわれた が, 出身地別的にながめると， 6 対 2 の割合で南 方出身者の方が初温に比して高く保った成績をえ たのであったが，乙れは附表に示すように，南方 出身者の方に皮下脂肪の厚い者が多かった影響の あらわれとみるべきである。

酸素消費量は寒冷曝露とともにいずれす上昇す るが、これを体表面積単位でながめると，多少の 
相異は認められるが，出身地，体格などの差によ っては特に認むべき相異を呈してはいない。さら に寒冷曝露から再び温暖所に帰った場合の状況に 差があるのではないかをうかでうために，寒冷曝 露前温暖所において 測定した酸素消費量に 比へ て, 寒冷曝露後再び温暖所に復帰した後20分目の それが上昇しているが，曝露中よりは明らかに低 下しているものをI とし，当初のそれと等しい か, あるいはかえってそれ以下に減少しているす のを扛しし，入室後あなお著しく六進しているも のを而としてながめた。しかしてれあ出身地およ び体格との相関は認めがたく，ただ同一人では毎 常等しい型をとる傾向が強く，またそれとともに その時の環境条件がこの型を規定するのにかなり 関与する傾向がうかがわれた。

結局, 以上の成績では各被検者の耐寒性はその 出身地の南北の別は各人の個人差を越すほどのあ のはないと判ぜざるをえない。そうするとここに 3つの問題が持ちあがってくる。すなわち，その 1 は日本人におりる耐寒性の個人差はどうなって いるのかであり，その 2 はこの耐寒性比較実験で すちいた負荷寒威の強さが出身地の南北があたら す程度の差異判定の手段としては大に過ぎたので はないかというとと，さらにその 3 は $-30^{\circ} \mathrm{C} に$ あおよぶ北満の寒威は出身地のいかんを越して, すへての人々を到達しうべき適応の限界点にまで 等しく持ち来たしていたのではなかろうかという ことである。

\section{III 対寒性の個人差と耐寒性判定にあた っての至適負荷刺激強度}

耐寒性の個人差判定は 1965 年からはじまった 国際生物学事業計画(IBP, International Biological Programme) の「ヒトの適応」部門での全世 界の各人種についての耐寒性ならびに耐熱性の比 較計画に関連してくる。IBP ではての目的のため に，世界各地において，同一な判定法之基準のあ とに測定值を比較することが要求せられたわけで あるが，筆者らむとれに参画して，耐寒性の判定 法として被検者を低温に曝露させている間の皮店 温の下降度 $(\Delta \mathrm{T})$ と産熱増進度 $(\Delta \mathrm{M})$ の相関から 決定する方法を提案したら)。乙の方法を考えた基 盤は, 従来の経験から, 耐寒性の強い者は弱い者
に比して冬季の通常生活中に遭遇する寒冷曝露程 度なら産熱增進度が小さいのを通則とするととに ある。この方法は米国の Carlson 教授 ${ }^{2}$ によって も全く同範塁の提案がなされているのであって, 現在，日本において筆者らの判定法をあちいた研 究成績がかなり多数に報告されている。

図 2 はこの方法に準拠した方法 $(\Delta \mathrm{M} / \mathrm{Ts})$ をす ちいて日本人の耐寒性強者群 $(\mathrm{J}-1)$ と弱者群 $(\mathrm{J}-$ 2) の成績を Carlson 教授の集めた白人ならびに エスキモーの平均値と比較したあのである。これ によってうかがわれるととは, 日本人の耐寒性の 強い者のうちには, 通常の日本の冬季の低温中の
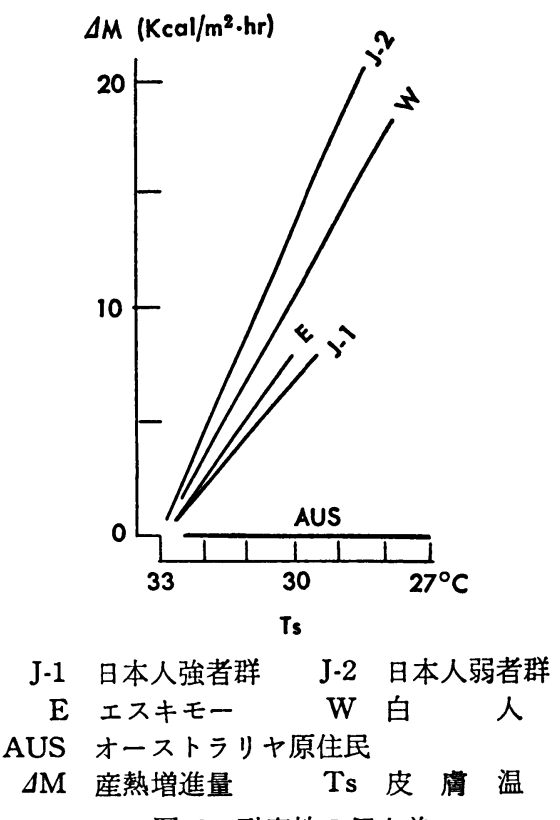

図 2 耐寒性の個人差

薄着装で全身平均皮膚温が $33^{\circ} \sim 27^{\circ} \mathrm{Cを}$ 呈する程 度の寒威では, 反応を全然呈しなかったオースト ラリヤ原住民にはおよばないが，エスキモーの平 均值に優る者があるととあに，弱い者が白人のそ れに劣っているあのああるのであって，日本人の 耐寒性に大きな個人差があることがうかがわれ る。

ところが筆者らの経験では，本困の成績は曝露 される低温環境としては $+10^{\circ} \mathrm{C}$, 着装は $1.7 \mathrm{clo}$ をあちいたあのであるが, これを $+5^{\circ} \mathrm{C}, 1.7 \mathrm{clo}$ とすると $\Delta \mathrm{M} / \Delta \mathrm{T}$ で表わされる被検者の耐寒性の 差の程度はずうっと小さくなり，各個人間のバラ ッキが接近してあらわれることに気づいた。そう 
すると小さい個人差まであをつかまえるためには $+10^{\circ} \mathrm{C}$ 環境をあちいた方が $+5^{\circ} \mathrm{C}$ 環境よりあ好 ましいということになる。これは耐寒性比較試験 には負荷すべき寒冷の強さということが大きく関 係することを物がたっており，そうすると上記の 提訴その 2 ，すなわち鍛練効果の判定にあたって の負荷刺激には求むる対象の種類によって定まる 至適強度の存するととを意味するとととなる。

\section{IV 鐉練効果の限界}

筆者はさらに上記の佳木斯実験の結果とあわせ て, 対寒適応の限界という問題についてつぎのよ うな経験を持っている。それは北満双城堡（ハル ピン近郊）の中国人の貧しい農民について12月に 観察したあのである ${ }^{6)}$ 。当時の 外気温は $-20^{\circ} \sim$ ー30ㄷ であったのに，乙の被検者たちの居住す る家屋の 1 日平均室温は $6.1^{\circ} \mathrm{C}$ であり, しかむ彼 らの着装は手足の直接凍傷にかかりやすいととろ は守っているが, その他は上下とも木綿の下衣に 綿入れの上衣 1 枚であって, 外套類を所持せず, いわば常にわずかな全財産を身につけている状態 であった。てのような生活様式をあってしてあ, 彼らがあし十分に北満の 冬季に 耐えうるとすれ ば，その強靯な耐寒性は感服に価し，また自然の うちに獲得したすのと考えられる対寒鍛練の効果 に対しては目をみはらねばならぬことになる。な んとなれば寒冷に曝露される場合には, 曝露前に 比較的高温な室に居住した者は，そうでない者に 比して感覚的に楽であるのみならず, 代謝六進の 程度も小さく，また低温室滞在時間が短かいか, あるいは十分に防寒具を身につけている時はてれ また代謝え進は小さいてとが明らかにされている が，この被検者たちの場合はそのいずれにも該当 しないからである。

図 3 はかかる農夫 $\mathrm{A}, \mathrm{B}$ の 2 名と, 対照として 南満からやってきた筆者らの 1 人 C とを同時に寒 冷にさらした場合のふるえの消長を産熱量の大き さから比較したあのである6)。AとBには，上記 のような彼らの日常の外出服装をつけさせている のに対して, 対照者Cでは筆者らの常識的な冬季 服装であるモメリヤス上下各 1 枚, 背広冬服, そ れに外套で, 両者とむ防寒帽, 防寒靴, 防寒手袋 はつけている。乙うして $10.1^{\circ} \mathrm{C}$ の室内に 3 人を

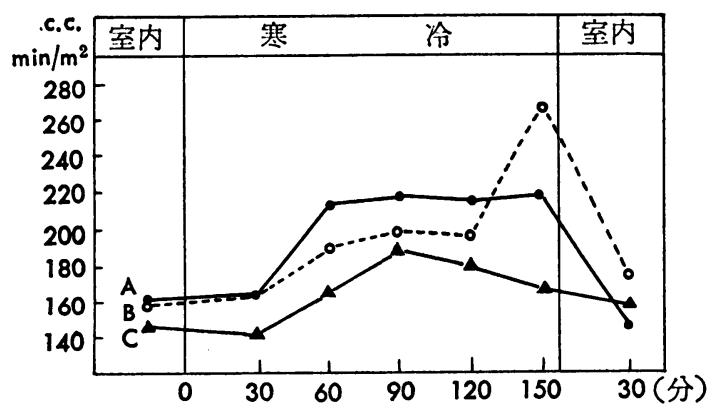

\section{A，B 中国人農夫酸素消費量 \\ C 日本内地人酸菜消費量 \\ 室内 $10^{\circ} \sim 12^{\circ} \mathrm{C}$ 寒冷 $-19^{\circ} \mathrm{C}$}

因 3 寒冷曝露比較試験

1 時間留置し, しかる後に $-16^{\circ} \sim-19^{\circ} \mathrm{C}$ の戸外 に 155 分間椅子に坐らせた。その成績は室内にお いてすでに薄着の A た寒冷曝露中も終始 $\mathrm{C}$ の方が代謝六進の程度が小 さい。感覚的にも 120 分を過ぎるころからA，B 両人は深刻な寒苦を訴えつづけたがCはこれに比 すればはるかに自覚的にも楽であった。

以上の成績は，秋よりはじまる貧農 $\mathrm{A}, \mathrm{B}$ の彼 らの生活様式強いられた対寒錹練の効果も, 特別の鉎練は行なったととのない南満居住の医師 Cのこの程度の服装に著しく劣るととを示してい るあのであって, 満洲のような寒冷地に居住する 者たちにとっては，それが北満であるか南満であ るかにかかわらず，特に鉎練を行なうことがなく てむ，天然の季節的影響はすでに十分な強度にお いて居住者の身体に強く作用しているすのと解し てさしつかえないであろう。てれに類する事象と して，筆者らはさらにつぎのような経験を持って いる。それは満洲居住の中国人で，1 年中を高温 な職場で働いている支那風呂の三助と, 終日夜半 まであ厳冬でも屋外にたたずんで客待ちをする人 力車夫の 2 人を, 同じ服装で同時に真冬の寒さに さらしてみた。定めし車夫は三助より強かろうと 想像していたのに，両者の間にはまったく差異は 認められず，一方が寒さにまいった時には，他方 あおなじく弱ってしまったのであった。

てのようにながめてくると，いたずらな銭練は 単に銭練のための鈠練とでも称すべき心理的な問 題の範囲にとどまる場合を生じうるのではないか と考えられる。ただしてのような判断は日本人と 
中国人を同一程度の耐寒性を遺伝的に有する者た ちであるという基盤の上にながめた場合の話であ って，乙の他の実験成績からも筆者は両民族が同 程度の耐寒性を持つものと推察している。しかし 同じ満洲に住む民族のうちであオロチョン族ので ときははるかに強い耐寒性を有することが想像で きる。

\section{V 鐉錬効果限界内での比較}

上述した佳木斯実験の寒冷条件よりあ緩和な条 件下の実験と目されるものに北大の伊藤真次教授 一門の成績がある ${ }^{3)}$ 。同氏らは(1)本州出身札㹸在 住者（札幌在住平均 5 年）6名，(2)北海道内出身 札幌在住者19名，(3)北海道上川郡風連町出身同地 在住者15名の男子について, 空腹時血漿脂質濃度 を比較した。その中でも夏冬にはっきりした差異 を呈する遊離脂肪酸濃度を比較した。その結果は 風連居住者が最も低く，北海道生れ札幌在住者が とれにつき，本州生れ札棍在住者が最も高い。同 氏はてのような事象は対寒産熱增進の熱源として 利用されるために必要な脂肪の交替(turnover)の 活発さの相異を意味するものとなしている。さら に寒冷昇圧反応にあ各群の間に歴然たる差異があ るという。

以上の成績は北海道出身者と本州出身者との間 に対寒反応の態勢に差異を有することを示してい るあのである。そうするとてれは上述した佳木斯 実験の成績と照しあわせると，適応には達しうる 限界が存するという考え方のたしからしさがます ます濃厚になる。

伊藤教授はまた本州および北海道出身者おのお の25名ずつの男子学生について, $0^{\circ} \mathrm{C}$ の冷水にひ たした示指皮䧹温の変動を測定し，ての反応に関 しては両者の間に差異がなかったてとを報告して いる。冷水の中に手指を入れると，その部の皮店 温は急激に下降するが，やがて周期的な寒冷血管 開張反応 (hunting reaction) が現われる。とれ は指に存在する動静脈吻合枝という血管が寒冷に 際会する場合に現わす反応であって，皮席温の異 常下降に対する防衛機転である。吉村寿人教授 ${ }^{8)}$ はこの反応をむちいて耐凍傷性を判断する凍傷ポ イントテスト法を考案しているが，ての方法をも ちいて氷水浴の反復はこの反応を増強させること
を証明しているし，またそれよりすさきに久野教 授一門4) は京都の鴨川の冷流中で友禅さらしに永 年従事する職人の足指温が冷水中で著しい反発性 の上昇を招来していることを明らかにしている。 ところが上述の伊藤教授らの成績では本州出身者 と北海道出身者間に脂肪代謝や，寒冷昇圧反応に は差異があるのに，寒冷皮膚血管反応は有意差が ないという。これは寒冷血管反纫の方は両群とも にすでに鉞練効果の上限值的な反応出現にまで達 しており，ひいては現象的にはかえって両者の差 異が認めにくくなったものと解される。伊藤教授 は全身性の寒冷適応にくらへて局所性のそれは比 較的容易に獲得されるすのであるかす知れないと されているが，筆者もそれとまったく見解を同じ くする。

\section{VIむす ひ}

上述の諸事象を通じてうかがわれる対寒鍛練効 果なるものには，少なくとも 2 つの面が共存して いることを認めざるをえない。すなわちその $1 つ$ は鍛練はたしかに大きな適応効果をよびおこしう

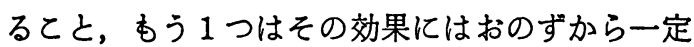
の限界が存しているらしいてとである。そうする と鍛練の効果は寒冷の害のようやく現われようと する一定範囲の条件内に限り，その偉力をひきお こすととができるむのであって，その範囲を越え た鍛練は役に立たないのみならず，身体障害をひ きおてすあとになることである。害を受けずに利 益ばかりを受けようとするとてろに鍛練の要点は なければならない。この関係は病気の治療に劇薬 があちいられる場合と同じととで, 薬量が適当で あれば著功があらわれるが，分量を過ごすと命と りになりかねない。しかむむつかしいてとには， 寒さでの分量決定は，楽のように何グラムでは計 れない。それかといって手びかえしたのでは最上 の鍛練効果は望めない。やるかきりは，少なくと あその効果が十分に発揮されるまでやらねばなら ぬ。

とのととに対処する目やすとしては，筆者はつ ぎのように考えている。すなわち 鉎練の 適量と は，その強さを考慮するととあ必要であろうか， それにあましてそれを行なう時間をいくばくにす るかにあると思う。鍛練だ鉎練だで，1 日中のへ 
つ幕なしに寒さに身をさらしていたり，過ぎた薄 着や火の気なしの冬季生活を龯練のように心得て いたのでは，日本の冬をわざわざ満洲にし，ある いは南極にして暮らすととになりはしないであろ うか。あっとあとのような鍛練 あ, 満洲でくら し, あるいは南極で越冬することそのあのがその 行動の目的であるような特例的な場合に限っては 通ずるかもしれないが，通常人にとってはそこに はおのずからてれとは異なった鉎練に対する考え 方が打ち出されてきよう。

すなわち，普通の健康者である限りにおいて は, 裸体操も結構, 乾布摩擦, 冷水摩擦もまたよ し，しかしそれには厳に適当な一定時間だけに限 らなければならないというととが肝腎であろう。 この一定時間の鈠練の間に獲得した効果を生かし ながら，それ以外の 1 日の大部分を占める生活時 間中では, 防寒具結構, 暖房あまたよしで, あら ゆる文明の恩惠に守られながら，作業能率の増進 をはかるところに, 最す有効な現代人の生活が展 開されるへきものであることを信ずる。

\section{引用文献}

1) Adolph, E.F., Burton, A.C. (1951) Cited from Ferrer, M.I. : Cold Injury, Transactions of the first Conference, sponsored by the Josiah Macy, JR. Foundation, New York, p. 181-187.

2) Carlson, L.D.(1965) Cold, in Edholm, O.G. and Bacharch, A.L. : The Physiology of Human Survival, Academic Press, London and New York, 15-51.

3）伊藤真次（1970）寒さに対する人体の適応， Medica, 7, 1852-1856.

4) 久野 㸘 (1949) 気候と人生, 創元社, 大阪,

5) Ogata, K.(1971) Physiological approach to the adaptability to cold and heat, Bull. Inst. Constit. Med. Kumamoto Univ., 21, Suppl., 1-62.

6) 緒方維弘 (1946) 寒冷と体温調節, 南条書店, 東京。

7）緒方維弘（1973）適応一気候風土に対する適 応, 医歯楽出版社, 東京。

8) Yoshimura, Y. and Iida (1952) Studies on the reactivity of skin vessels to extreme cold, Jap, J. Physiol., 1, 147-159 and 2, 118121. 